\title{
Analysis of Helicobacter pylori Genotypes in Afghani and Iranian Isolates
}

\author{
HOSSEIN DABIRI $^{1,2^{*}}$, MEHDI BOLFION ${ }^{1}$, AKBAR MIRSALEHIAN $^{2}$, MARYAM REZADEHBASHI $^{1}$, \\ FERESHTEH JAFARI ${ }^{1}$, LEILA SHOKRZADEH ${ }^{1}$, NAVID SAHEBEKHTIARI ${ }^{1}$, HOMAYON ZOJAJI ${ }^{1}$, \\ YOSHIO YAMAOKA ${ }^{3}$, DARIOUSH MIRSATTARI ${ }^{1}$, MOHAMMAD REZA ZALI ${ }^{1}$ \\ ${ }^{1}$ Research Center for Gastroenterology and Liver Diseases in Shaheed Beheshti University, M.C., Tehran, Iran \\ ${ }^{2}$ Department of Microbiology, School of Medicine, Tehran University of Medical Sciences, Tehran, Iran. \\ ${ }^{3}$ Department of Medicine-Gastroenterology, Michael E. DeBakey Veterans Affairs Medical Center \\ and Baylor College of Medicine, Houston, Texas, USA
}

Received 2 February 2010, revised 20 January 2010, accepted 21 January 2010

\begin{abstract}
The geographical variation in Helicobacter pylori genotypes is an observed phenomenon. Cytotoxin associated genes $\mathrm{A}(\mathrm{cag} A)$ and $\mathrm{E}(\mathrm{cag} E)$, and vacuolating cytotoxin ( $v a c A)$ genotypes of $\mathrm{H}$. pylori are associated with peptic ulcer disease (PUD). This study compared the distribution of these genotypes in Iranian and Afghani isolates and their association with clinical outcomes. H. pylori infected patients, as proven by positive culture, were recruited prospectively. A total of 70 patients, 55 Iranian (26 men and 29 women, mean age $48 \pm 18$ years) and 15 Afghani immigrants (13 men and 2 women, mean age $34.8 \pm 11$ years) living in Tehran, Iran were enrolled in this study. DNA was extracted from isolated $H$. pylori and polymerase chain reaction was carried out to determine the $\operatorname{cag} A$ and $\operatorname{cag} E$ status and $v a c A$ alleles. The number of gastric cancer, peptic ulcer and gastritis cases was 11,23 and 36 , respectively. The $c a g A$ positive isolates were more common in Iranian (67\%) than Afghani isolates (60\%). cagE was positive in 53\% of Afghani compared to $51 \%$ of Iranian isolates. The most common vacA s-region genotype was s1; $80 \%$ in Afghani and $67 \%$ in Iranian. The s $1 \mathrm{~m} 1$ was a frequently observed genotype in Afghani strains $(53 \%)$ while s1m2 (47\%) was more common in strains isolated from Iranian patients. There is a difference in the H. pylori strains between Iranian and Afghani groups, for instance Iranian isolates were similar to European isolates while Afghani isolates were similar to isolates from India. However, there was no significant association between $\operatorname{cag} A, \operatorname{cag} E$ and $v a c A$ genotypes and clinical outcomes in Iranian and Afghani patients.
\end{abstract}

Ke y w ords: Afghani and Irani isolates of Helicobacter pylori, H. pylori genotypes, virulence factors, clinical outcome

\section{Introduction}

Helicobacter pylori genotypes and their geographic distribution are linked to the severity of peptic ulcer disease (PUD) (Van Doorn et al., 1998; Covacci et al., 1999). The H. pylori genome is genetically diverse, as it can be seen in the cag pathogenicity island (PAI) and allelic variation within the $v a c A$ gene (Van Doorn et al., 1998a; Covacci et al., 1999; Yamaoka et al., 1999). H. pylori infects the majority of the global population and more than $90 \%$ of the Iranian population is reported to be infected with H. pylori (Alborzi et al., 2006). H. pylori infection causes chronic gastritis, PUD, gastric carcinoma (GC) and MALT lymphoma (Marshall and Warren, 1984; Wotherspoon et al., 1991; Parsonnet et al., 1991). Several H. pylori virulent genes contribute to the risk and severity of the disease outcome. These include the cag PAI that encodes a type IV secretion system (Kuipers et al., 1995; Censini et al., 1996). The cytotoxin associated gene A $(\operatorname{cag} A)$ has been proposed as a marker for the cag PAI and is associated with more severe clinical outcomes (Van Doorn et al., 1998a; Atherton, 1997). The cag PAI genes contain a $c a g E$ gene that encodes a secretory protein that is required for the induction of interleukin IL-8 (Tummuru et al.,1995) and for translocation and phosphorylation of CagA protein (Odenbreit et al., 2000). The presence of the cagE gene has been associated with a severe clinical outcome, especially in developed countries (Fallone et al., 1998).

Vacuolating cytotoxin (vacA) is another important virulence factor of $H$. pylori that is associated with injury to epithelial cells. The vacA gene is virtually present in all $H$. pylori and has at least two variable parts, the signal or s-region, and the middle or m-region (Atherton et al., 1995). To date, s region and

* Corresponding author: H. Dabiri, Research Center for Gastroenterology and Liver Diseases in Shaheed Beheshti University, M.C., Tehran, Iran; phone: (0098)9122839824; fax: 0098-21-22432517; e-mail: hdabiri@razi.tums.ac.ir 
Table I

Oligonucleotide primers used in genotyping of $H$. pylori isolates

\begin{tabular}{|c|c|c|c|c|}
\hline Gene & $\begin{array}{c}\text { Primer } \\
\text { designation }\end{array}$ & Sequence & $\begin{array}{l}\text { PCR product } \\
\text { size }(\mathrm{bp})\end{array}$ & Reference \\
\hline $\operatorname{glm} \mathbf{M}$ & $\begin{array}{l}\text { GlmM1-R } \\
\text { GlmM2-F }\end{array}$ & $\begin{array}{l}\text { GCTTACTTTCTAACACTAACGCGC } \\
\text { GGATAAGCTTTTAGGGGTGTTAGGGG }\end{array}$ & 296 & (Kauser et al., 2005) \\
\hline$v a c A s 1$ and $\mathrm{s} 2$ & $\begin{array}{l}\text { VAIF } \\
\text { VAIXR }\end{array}$ & $\begin{array}{l}\text { ATGAAAAAAACCCTTTTAC } \\
\text { CGAATTGCAAGTGATGGT }\end{array}$ & $\begin{array}{l}259(\mathrm{~s} 1) \\
286(\mathrm{~s} 2)\end{array}$ & (Kauser et al., 2005) \\
\hline$v a c A$ m1 & $\begin{array}{l}\text { VAG-F } \\
\text { VAGR }\end{array}$ & $\begin{array}{l}\text { CAATCTGTCCAATCAAGCGAG } \\
\text { GCGTCTAAATAATTCCAAGG }\end{array}$ & 570 & (Yamaoka et al., 1999) \\
\hline$v a c A \mathbf{m} 2$ & $\begin{array}{l}\text { VAG-F } \\
\text { VAG-R }\end{array}$ & $\begin{array}{l}\text { CAATCTGTCCAATCAAGCGAG } \\
\text { GCGTCTAAATAATTCCAAGG }\end{array}$ & 645 & (Yamaoka et al., 1999) \\
\hline $\operatorname{cag} A$ & $\begin{array}{l}\text { CagA F1 } \\
\text { CagA R1 }\end{array}$ & $\begin{array}{l}\text { AACAGGACAAGTAGCTAGCC } \\
\text { TATTAATGCGTGTGTGGCTG }\end{array}$ & 349 & (Kauser et al., 2005) \\
\hline $\operatorname{cag} E$ & $\begin{array}{l}\text { picBF } \\
\text { picBR }\end{array}$ & $\begin{array}{l}\text { TGTTTGGTTTCCCTG } \\
\text { ACGCATTCCTTAACG }\end{array}$ & 1335 & (Tan, et al., 2005) \\
\hline
\end{tabular}

$\mathrm{m}$ region can be differentiated to $\mathrm{s} 1 \mathrm{a}, \mathrm{s} 1 \mathrm{~b}, \mathrm{~s} 1 \mathrm{c}, \mathrm{s} 2$ and $\mathrm{m} 1 \mathrm{a}, \mathrm{m} 1 \mathrm{~b}, \mathrm{~m} 1 \mathrm{c}, \mathrm{m} 2$ subtypes respectively. The different combination of $\mathrm{s}$ - and m-region allelic types determines the production of the cytotoxin and the pathogenicity of the organism. vacA $\mathrm{m} 1$ strains are associated with greater gastric epithelial damage than $\mathrm{m} 2$ strains (Atherton et al., 1995). vacA $\mathrm{s} 1 \mathrm{~m} 1$ strains produce a large quantity of toxins, and $\mathrm{s} 2 \mathrm{~m} 2$ strains produce very little or no toxins. $v a c A$ sla strains appear to be more pathogenic than s1b or s2 strains (Covacci et al., 1999; Saribasak et al., 2004; Blaser, 1995), although these are not consistent (Mohammadi et al., 2003; Mukhopadhyay et al., 2000; Tan et al., 2005). Respect to geographic variation in the vacA genotypes (Yamaoka et al., 1999; Tan et al., 2005; Van Doorn et al., 1999), it is suggested that such variations may contribute to the different prevalence of gastric diseases in these areas.

Iran and Afghanistan are neighboring countries and there are many Afghani refugees in Iran. Although there are several recent studies examining the relationship between $H$. pylori virulence factors and clinical outcomes in Iran (Mohammadi et al., 2003; Hussein et al., 2008); however, there is no report about relationship between Iranian and Afghani H. pylori virulence factors. We therefore compared the distribution of $v a c A$ alleles, $\operatorname{cag} A$ and $\operatorname{cag} E$ status in Iranian and Afghanis residing in Tehran, Iran, and their association with clinical outcome.

\section{Experimental}

\section{Material and Methods}

Studied Population. A total of 70 patients from Iran and Afghanistan living in Tehran, Iran who were subjected to upper endoscopy from February 2007 to
May 2008, were enrolled in this study. None of the patients had received non-steroid anti-inflammatory drugs or antibiotics within the previous three months. Informed consent was obtained from all patients, and the protocol was approved by the ethical committee of Research Center for Gastroenterology and Liver Diseases in Shaheed Beheshti University of Medical Science.

Isolation and identification. Three biopsy specimens were taken from the greater curve of the antrum; two were used for histological examination and one for H. pylori culture. Gastric biopsy specimens for culture were kept in transport medium consisting of thioglycolate with $1.3 \mathrm{~g} / \mathrm{l}$ agar (Merck Co, Homburg, Germany) with 3\% yeast extract (Oxoid Ltd., Basingstoke, UK) and were delivered to the laboratory on the day of endoscopy. In each case, the gastric biopsy specimens were cultured on Brucella Agar with $7 \%$ sheep blood and supplements with different antibiotics (Merck, Homburg, Germany) and incubated under microaerophilic conditions at $37^{\circ} \mathrm{C}$ for 3-10 days. The organisms were identified as H. pylori by colony morphology, gram staining results and positive reactions to oxidase, catalase, and urease activities. The identified $H$. pylori were sub-cultured and single colonies were used for DNA extraction.

Preparation of genomic DNA and Polymerase Chain Reaction (PCR). DNA from each H. pylori isolate was extracted using a commercially available kit (Qiagen, Hilden, Germany). The genotypes of vacA s-region (s1 or s2) and $\mathrm{m}$-region ( $\mathrm{m} 1$ or $\mathrm{m} 2)$, the presence of the $\operatorname{cag} A, \operatorname{cag} E$ and $\operatorname{glm} M($ ureC) genes were determined by PCR. The $g \operatorname{lm} M(u r e C)$ gene was used as controls for detecting $H$. pylori DNA. Primers sequences used in this study are listed in Table I. All PCR mixtures were prepared in a volume of $25 \mu \mathrm{L}$ containing $1 \times \mathrm{PCR}$ buffer, $500 \mathrm{nM}$ of each primer, $1.5 \mathrm{mM} \mathrm{MgCl}_{2} ; 200 \mu \mathrm{M}$ each dNTP, $1.5 \mathrm{U}$ Taq DNA 
polymerase, and $300 \mathrm{ng}$ DNA sample. The products were amplified in an Eppendorf AG 22331 thermocycler (Eppendorf, Hamburg, Germany), and visualized by electrophoresis in $1.5 \%$ agarose gel, stained with ethidium bromide, and examined under UV illumination. Mixed infection of different genotypes and $v a c A$ negative samples were excluded in the analyses.

Data Analysis. Chi Square and Fisher's exact tests were used for analysis of categorical data and ANOVA for continuing data. Analyses were done using Sigma Stat for Windows V2.03 (SPSS, Chicago, IL). A p value less than 0.05 was accepted as statistically significant.

\section{Results}

A total of 70 patients, 55 Iranian (26 men and 29 women, mean age $48 \pm 18$ years) and 15 Afghani immigrants (13 men and 2 woman, mean age $34.8 \pm$ 11 years) living in Tehran, Iran, were enrolled in this study (Table II). Distribution of gastric cancer, peptic ulcer, and gastritis, was 11, 23 and 36, respectively. The $\operatorname{cag} A$ positive isolates were more common in Iranian 37 (67\%) than Afghani isolates $9(60 \%)$. The cagA gene was present in $62 \%, 64 \%$ and $74 \%$ of $\mathrm{H}$. pylori strains isolated from Iranian patients with, PUD, GC and NUD, respectively, while 50\% PUD and 61\% NUD of Afghani patients were infected with $\operatorname{cag} A$ positive $H$. pylori isolates. The presence of the $\operatorname{cag} A$ gene was not statistically correlated with the presence of PUD or GC in both countries. cagE was positive in $53 \%$ of Afghani compare to $51 \%$ of Iranian isolates. Regardless of ethnic differences, statistically there was no association between $\operatorname{cag} E$ status and clinical outcome.

The most common vacA s-region genotype was s1; the numbers vary from $80 \%$ in Afghani to $67 \%$ in Iranian isolates. For the vacA m-region, $\mathrm{m} 1$ genotype was the most common among Afghani strains (53\%), while $\mathrm{m} 2$ genotype was the most common (69\%) in strains isolated from Iranian patients. The $\mathrm{s} 1 \mathrm{~m} 1$ $(53 \%)$ was a genotype frequently observed in Afghani strains while $\mathrm{s} 1 \mathrm{~m} 2(47 \%)$ was more common in strains isolated from Iranian patients. In Iranian samples 2 $(4 \%)$ isolates were $\mathrm{s} 0 \mathrm{~m} 2$ (with no PCR product for $\mathrm{s}$ region) while such genotype was not seen in Afghani isolates. there was no statistically significant association between clinical outcomes and $v a c A$ genotypes in each ethnic group, however the allotype distribution of vacA in clinical outcome groups (NUD, PUD and GC) showed a different profile in the two nations $(p=0.08)$. There was also no significant difference in the prevalence of triple positive (vacA s1, cagA and $\operatorname{cag} E$ ) strains between PUD and NUD patients.

We also classified the gastritis cases with no acute inflammation (polymorphonuclear cell infiltration), none to severe chronic inflammation (mononuclear cell infiltration) as well as no gastric atrophy/intestinal metaplasia as "mild to severe gastritis", and analyzed separately; however the prevalence of the $\operatorname{cag} A$ gene in strains isolated from patients with mild gastritis was even higher than those with total gastritis as well as those with PUD and GC, indicating that the $\operatorname{cag} A$ gene was not involved in the severity of gastritis in either nationality.

\section{Discussion}

This study investigated the $\operatorname{cag} A, \operatorname{cag} E$ and $v a c A$ status of $H$. pylori isolated from patients from Iran and Afghanistan living in Tehran. All Afghani patients were born in Afghanistan and immigrated to Iran. Because the strains were obtained from symptomatic patients, the results reflect the findings in these groups of patients rather than entire populations. The current study confirms the distinctive difference in $H$. pylori genotypes in Iranian and Afghani patients even they residing within the same city. This is consistent with other studies from the USA, Malaysia and Kuwait (Tan et al., 2005; Yamaoka et al., 2000; Qabandi et al., 2005). The difference in $H$. pylori strains among different ethnic groups living in the same area suggests that they were brought by immigrants and have remained in that population for many generations (Dabiri et al., 2009; Tan et al., 2005).

Table II

Demographic characterization and clinical outcomes in 70 studied patients

\begin{tabular}{|l|c|c|c|c|c|c|c|c|c|}
\hline \multirow{2}{*}{ Ethnicity } & \multirow{2}{*}{ Number } & \multicolumn{2}{|c|}{ Sex } & \multicolumn{3}{|c|}{ Gastritis (NUD) } & \multirow{2}{*}{ PUD } & \multirow{2}{*}{ GC } \\
\cline { 7 - 9 } & & Male & Female & & Mild & Moderate & Sever & & \\
\hline Iranian & 55 & $26(47 \%)$ & $29(53 \%)$ & $48 \pm 18$ & $7(13 \%)$ & $12(22 \%)$ & $4(7 \%)$ & $21(38 \%)$ & $11(20 \%)$ \\
\hline Afghan & 15 & $13(87 \%)$ & $2(13 \%)$ & $35 \pm 11$ & $5(34 \%)$ & $6(40 \%)$ & $2(13 \%)$ & $2(13 \%)$ & $0(0 \%)$ \\
\hline Total & 70 & $39(56 \%)$ & $31(44 \%)$ & $46 \pm 18$ & $12(17 \%)$ & $18(26 \%)$ & $6(8 \%)$ & $23(33 \%)$ & $11(16 \%)$ \\
\hline P value & - & \multicolumn{3}{|c|}{0.06} & - & \multicolumn{7}{|c|}{0.8} & & 0.1 & - \\
\hline
\end{tabular}

P value is calculated by comparing demographic characterization and clinical outcomes (NUD, PUD and GC) in two nations. NUD, Non Ulcer Dyspepsia; PUD, Peptic Ulcer Disease; GC, Gastric Carcinoma. 
H. pylori vacA s1 was the predominant genotype in both country isolates. The $v a c A \mathrm{~s} 1 \mathrm{~m} 2$ genotype was predominant in Iranian strains similar to reports from Western countries (Saribasak et al., 2004). In contrast, s1m1 genotype was predominant in Afghani strains similar to reports from India (Yamaoka et al., 1999; Chattopadhyay et al., 2002). Different pattern of vacA alleles in association with clinical outcomes in each nation is probably suggesting that Iranian and Afghani H. pylori isolates possess different virulence.

The prevalence of the $\operatorname{cag} A$ gene has been reported to vary from $26 \%$ in Jordan to $100 \%$ in India (Nimri et al., 2006; Datta et al., 2003). Such differences were attributed to the genetic diversity and geographic locations (Covacci et al., 1999). cagA presence in Iranian isolates has been reported to vary from $44 \%$ to $91 \%$ according to different reports (Dabiri et al., 2009; Siavoshi et al., 2005; Talebkhan et al., 2008). In the present study, $67 \%$ of the Iranian patients were infected with $\operatorname{cag} A$ positive strains similar to an Iranian report (67\%) (Dabiri et al., 2009; Jafarzadeh et al., 2007). This is relatively different from studies in Asian countries such as Japan, Korea, China, Hong Kong, Malaysia, Thailand and India where more than $90 \%$ of the strains carry the $\operatorname{cag} A$ gene, regardless of clinical outcomes (Yamaoka et al., 1999; Tan et al., 2005; Datta et al., 2003; Pan et al., 1998; Wong et al., 2001; Chomvarin et al., 2008). Our results regarding strains isolated from Iranians are rather consistent with studies from Europe and the US where the prevalence of $\operatorname{cag} A$ positive strains is between $60-70 \%$ (Van Doorn, L.J., et al., 1998a; Miehlke et al., 2000). The prevalence of cagA positive strains in Afghans (60\%) is in agreement with previous reports from neighborhood of Afghanistan; Iran $(\sim 70 \%)$ and Bangladesh $(55 \%)$ and despite of high prevalence of $\mathrm{cagA}$ positive strains (100\%) in India (Datta et al., 2003, Talebkhan et al., 2008; Rahman et al., 2003).

The presence of the $\operatorname{cag} E$ gene was also reported to vary in different geographic regions and/or ethnic groups (e.g., $64 \%$ in the US, $71 \%$ in UK, $70 \%$ in Malay, $88 \%$ in Thailand, $28 \%$ in Turkey and $77 \%$ [NUD] to $92 \%$ [PUD] in India) (Tan et al., 2005; Chomvarin et al., 2008; Podzorski et al., 2003; Kauser et al., 2005; Tiwari et al., 2005; Salih et al., 2007). The prevalence of the $\operatorname{cag} E$ gene in studied isolates from both countries was close to each other $(51 \%$ in Iranian vs. $53 \%$ in Afghani isolates) and different with other countries. This finding was different with very limited report on only three Afghani samples (Dabiri et al., 2009).

The present study did not reveal any associations of the vacA and cagA status with PUD and NUD in both ethnics. This finding is in agreement with other reports from Iran (Hussein et al., 2008; Talebkhan et al., 2008) but was different from that in many stud- ies in Western countries where vacA s1 and $\operatorname{cag} A$ positive strains are more often isolated from patients with PUD than with NUD (Blaser, 1995). The difference in the cagA status and its association with clinical outcomes might be due to large genomic variations in the $H$. pylori genomes. There may be several distinct forms of the cagA gene with an uneven geographical distribution, and that only some forms of the $\operatorname{cag} A$ gene are associated with severe gastroduodenal diseases (Miehlke et al., 1996; Pan et al., 1997; Zhou et al., 2004).

Conclusions. The presented study detected differences between $H$. pylori isolates from Iranian and Afghani patients. Afghani isolates (in the case of vacA allele) are more similar to Indian isolates while in $\mathrm{cag}$ alleles are more similar to Iranian isolates. We could not detect any statically associations of the vacA, $\operatorname{cag} A$ and $\operatorname{cag} E$ status with clinical outcomes in Iranian and Afghani patients. Therefore, we suggest a different marker of $H$. pylori as a useful virulence marker for more serious disease in Iran and further studies with large number of samples for Afghanistan.

\section{Acknowledgements}

The authors are thankful to Dr M. Molaei and K. Baghaei for their technical helping. This study was supported by a grant from Research Center for Gastroenterology and liver Disease of Shaheed Beheshti University Research Fund, project number 407.

\section{Literature}

Alborzi A., J. Soltani, B. Pourabbas, B. Oboodi, M. Haghighat, M. Hayati and M. Rashidi. 2006. Prevalence of Helicobacter pylori infection in children (south of Iran). Diagn. Microbiol. Infect. Dis. 54: 259-261.

Atherton J.C. 1997. The clinical relevance of strain types of Helicobacter pylori. Gut. 40: 701-703.

Atherton J.C., P. Cao, R.M. Peek, M.K.R. Tummuru, M.J. Blaser and T.L. Cover. 1995. Mosaicism in vacuolating cytotoxin alleles of Helicobacter pylori Association of specific vacA types with cytotoxin production and peptic ulceration. J. Biol. Chem. 270: 17771-17767.

Blaser M.J. 1995. Intrastrain differences in Helicobacter pylori: a key question in mucosal damage? Ann Med. 27: 559-563.

Censini S., C. Lange, Z. Xiang, J.E. Crabtree, P. Ghiara, M. Borodovsky, R. Rappuoli and A. Covacci. 1996. Cag, a pathogenicity island of Helicobacter pylori, encodes type I-specific and disease-associated virulence factors. Proc. Natl. Acad. Sci. 93: 14648-14653.

Chattopadhyay S., S. Datta, A. Chowdhury, S. Chowdhury, A.K. Mukhopadhyay, K. Rajendran, S.K. Bhattacharya, D.E. Berg and G.B. Nair. 2002. Virulence genes in Helicobacter pylori strains from West Bengal residents with overt $H$. pyloriassociated disease and healthy volunteers. J. Clin. Microbiol. 40: 2622-2625.

Chomvarin C., W. Namwat, K. Chaicumpar, P. Mairiang, A. Sangchan, B. Sripa, S. Tor-Udom and R.K. Vilaichone. 2008. Prevalence of Helicobacter pylori vacA, cagA, cagE, iceA and babA2 genotypes in Thai dyspeptic patients. Int. J. Infect. Dis. 12: $30-36$. 
Covacci A., J.L. Telford, G. Del Giudice, J. Parsonnet and R. Rappuoli. 1999. Helicobacter pylori virulence and genetic geography. Science 284:1328-1333.

Dabiri H., P. Maleknejad, Y. Yamaoka, MM. Feizabadi, F. Jafari, M. Rezadehbashi, FA. Nakhjavani, A. Mirsalehian, M.R. Zali. 2009. Distribution of Helicobacter pylori cagA, cagE, oipA and $v a c A$ in different major ethnic groups in Tehran, Iran. J. Gastroenterol Hepatol. 24: 1380-1386.

Datta S., S. Chattopadhyay, G.B. Nair, A.K. Mukhopadhyay, J. Hembram, D.E. Berg, D.R. Saha, A. Khan, A. Santra, S.K. Bhattacharya and other. 2003. Virulence genes and neutral DNA markers of Helicobacter pylori isolates from different ethnic communities of West Bengal, India. J. Clin. Microbiol. 41: 3737-3743.

Fallone C.A., R. Beech and A. Barkun. 1998. The H. pylori $v a c A \mathrm{~S} 1$ genotype and the $c a g E$ gene are associated with gastroduodenal disease. Gut. 43 :19A

Hussein N.R., M. Mohammadi, Y. Talebkhan, M. Doraghi, D.P. Letley, M.K. Muhammad, R.H. Argent and J.C. Atherton. 2008. Differences in virulence markers between Helicobacter pylori strains from Iraq and those from Iran: potential importance of regional differences in H. pylori-associated disease. J. Clin. Microbiol. 46: 1774-1779.

Jafarzadeh A., M.T. Rezayati and M. Nemati. 2007. Specific serum immunoglobulin $\mathrm{G}$ to $H$. pylori and $\mathrm{CagA}$ in healthy children and adults (south-east of Iran). World. J. Gastroenterol. 13: 3117-3121

Kauser F., M.A. Hussain, I. Ahmed, N. Ahmad, A. Habeeb, A.A. Khan and N. Ahmed. 2005. Comparing genomes of Helicobacter pylori strains from the high-altitude desert of Ladakh, India. J. Clin. Microbiol. 43: 1538-1545.

Kauser F., M.A. Hussain, I. Ahmed, S. Srinivas, S.M. Devi, A.A. Majeed, K.R. Rao, A.A. Khan, L.A. Sechi and N. Ahmed. 2005. Comparative genomics of Helicobacter pylori isolates recovered from ulcer disease patients in England. BMC Microbiol. 5: 32. Kuipers E.J., I.P. Guillermo, S.G.M. Meuwissen and M.J. Blaser. 1995. Helicobacter pylori and atrophic gastritis: importance of the cagA status. J. Natl. Cancer. Inst. 87: 1777-1780.

Marshall B.J. and J.R. Warren. 1984. Unidentified curved bacilli in the stomach of patients with gastritis and peptic ulceration. Lancet. 1: 1311-1315.

Miehlke S., C. Kirsch, K. Agha-Amiri, T. Günther, N. Lehn, P. Malfertheiner, M. Stolte, G. Ehninger, E. Bayerdörffer. 2000. The Helicobacter pylori vacA $\mathrm{s} 1, \mathrm{~m} 1$ genotype and cagA is associated with gastric carcinoma in Germany. Int. J. Cancer. 87: $322-327$

Miehlke S., K. Kibler, J.G. Kim, N. Figura, S.M. Small, D.Y. Graham and M.F. Go. 1996. Allelic variation in the cagA gene of Helicobacter pylori obtained from Korea compared to the United States. Am. J. Gastroenterol. 91:1322-1325.

Mohammadi M., A. Oghalaie, N. Mohajerani, S. Massarrat, M. Nasiri, M. Bennedsen, H. Colding and L.P. Andersen. 2003. Prevalence of Helicobacter pylori vacuolating cytotoxin and its allelic mosaicism as a predictive marker for Iranian dyspeptic patients. Bull. Soc. Pathol. Exot. 96: 3-5.

Mukhopadhyay A.K., D. Kersulyte, J. Jeong, S. Datta, Y. Ito, A. Chowdhury, S. Chowdhury, A. Santra, S.K. Bhattacharya, T. Azuma and others. 2000. Distinctiveness of genotypes of Helicobacter pylori in Calcutta, India. J. Bacteriol. 182: 3219-3227.

Nimri L.F., I. Matalka, K.B. Hani and M. Ibrahim. 2006. Helicobacter pylori genotypes identified in gastric biopsy specimens from Jordanian patients. BMC Gastroenterol. 6: 27.

Odenbreit S., J. Püls, B. Sedlmaier, E. Gerland, W. Fischer and R. Haas. 2000. Translocation of Helicobacter pylori CagA into gastric epithelial cells by type IV secretion. Science. 287: $1497-1500$
Pan Z.J., D.E. Berg, R.W.M. Van Der Hulst, W.W. Su, A. Raudonikiene, S.D. Xiao, J. Dankert, G.N.J. Tytgat and A. Van Der Ende. 1998. Prevalence of vacuolating cytotoxin production and distribution of distinct vacA alleles in Helicobacter pylori from China. J. Infect. Dis. 178: 220-226.

Pan Z.J., R.W. Van Der Hulst, M. Feller, S.D. Xiao, G.N. Tytgat, J. Dankert and A. Van Der Ende. 1997. Equally high prevalence of infection with cagA-positive Helicobacter pylori in Chinese patients with peptic ulcer disease and those with chronic gastritis-associated dyspepsia. J. Clin. Microbiol. 35: 1344-1347.

Parsonnet J., G.D. Friedman, D.P. Vandersteen, Y. Chang, J.H. Vogelman, N. Orentreich and R.K. Sibley. 1991. Helicobacter pylori infection and the risk of gastric carcinoma. N. Engl. J. Med. 325: 1127-1131.

Podzorski R.P., D.S. Podzorski, A. Wuerth, V. Tolia. 2003 Analysis of the vacA, cagA, cagE, iceA, and babA2 genes in Helicobacter pylori from sixty-one pediatric patients from the Midwestern United States. Diagn. Microbiol. Infect. Dis. 46: 83-88. Qabandi A.A., A.S. Mustafa, I. Siddique, A.K. Khajah, J.P. Madda and T.A Junaid. 2005. Distribution of vacA and cagA genotypes of Helicobacter pylori in Kuwait. Acta. Trop. 93: 283-288.

Rahman M., A.K. Mukhopadhyay, S. Nahar, S. Datta, M. Mashhud Ahmad, S. Sarker, I.M. Masud, L. Engstrand, M.J. Albert and G.B. Nair. 2003. DNA-level characterization of Helicobacter pylori strains from patients with overt disease and with benign infections in Bangladesh. J. Clin. Microbiol. 41: 2008-2014.

Salih B.A., M.F. Abasiyanik and N. Ahmed. 2007. A preliminary study on the genetic profile of cag pathogenicity-island and other virulent gene loci of Helicobacter pylori strains from Turkey. Infect. Genet. Evol. 7: 509-512.

Saribasak H., B.A. Salih, Y. Yamaoka and E. Sander. 2004 Analysis of Helicobacter pylori genotypes and correlation with clinical outcome in Turkey. J. Clin. Microbiol. 42: 1648-1651.

Siavoshi F., R. Malekzadeh, M. Daneshmand and H. Ashktorab. 2005. Helicobacter pylori endemic and gastric disease. Dig. Dis. Sci. 50: 2075-2080.

Talebkhan Y., M. Mohammadi, M.A. Mohagheghi, H.R. Vaziri, M.E. Hosseini, N. Mohajerani, A. Oghalaei, M. Esmaeili and L. Zamaninia. 2008. CagA gene and protein status among Iranian Helicobacter pylori strains. Dig. Dis. Sci. 53: 925-932.

Tan H.J., A.M. Rizal, M.Y. Rosmadi and K.L. Goh. 2005. Distribution of Helicobacter pylori cagA, cagE and vacA in different ethnic groups in Kuala Lumpur, Malaysia. J. Gastroenterol. Hepatol. 20: 589-594.

Tiwari S.K., A.A. Khan, K.S. Ahmed, S.M Ali, I. Ahmed, A. Habeeb, F. Kauser, M.A. Hussain, N. Ahmed and C.M. Habibullah. 2005. Polymerase chain reaction based analysis of the cytotoxin associated gene pathogenicity island of Helicobacter pylori from saliva: an approach for rapid molecular genotyping in relation to disease status. J. Gastroenterol. Hepatol. 20: 1560-1566. Tummuru M.K., S.A. Sharma and M.J. Blaser. 1995. Helicobacter pylori picB, a homologue of the Bordetella pertussis toxin secretion protein, is required for induction of IL-8 in gastric epithelial cells. Mol. Microbiol. 18: 867-876.

Van Doorn L.J., C. Figueiredo, F. Mégraud, S. Pena, P. Midolo, D.M. Queiroz, F. Carneiro, B. Vanderborght, M.D. Pegado, R. Sanna and others. 1999. Geographic distribution of vacA allelic types of Helicobacter pylori. Gastroenterology. 116: 823-830. Van Doorn L.J., C. Figueiredo, R. Rossau, G. Jannes, M. van Asbroeck, J.C. Sousa, F. Carneiro and W.G.V. Quint. 1998. Typing of Helicobacter pylori vacA gene and detection of cagA gene by PCR and reverse hybridization. J. Clin. Microbiol. 36: $1271-1276$ 
Van Doorn L.J., C. Figueiredo, R. Sanna, A. Plaisier, P. Schneeberger, W.D. Boer and W. Quint. 1998a. Clinical relevance of the $\operatorname{cag} A, v a c A$, and iceA status of Helicobacter pylori. Gastroenterology. 115: 58-66.

Wong B.C.Y., Y. Yin, D.E. Berg, H.H.X. Xia, J.Z. Zhang, W.H. Wang, W.M. Wong, X.R. Huang, V.S.Y. Tang and S.K. Lam. 2001 Distribution of distinct vacA, cagA and iceA alleles in Helicobacter pylori in Hong Kong. Helicobacter. 6: 317-324.

Wotherspoon A.C., C. Ortiz-Hidalgo, M.R. Falzon and P.G. Isaacson. 1991. Helicobacter pylori-associated gastritis and primary B-cell gastric lymphoma. Lancet. 338:1175-1176.
Yamaoka Y., H.M. Malaty, M.S. Osato and D.Y. Graham. 2000. Conservation of Helicobacter pylori genotypes in different ethnic groups in Houston, Texas. J. Infect. Dis. 181: 2083-2086.

Yamaoka Y., T. Kodama, O. Gutierrez, J.G. Kim, K. Kashima and D.Y. Graham. 1999. Relationship between Helicobacter pylori ice $A, \operatorname{cag} A$, and $v a c A$ status and clinical outcome: studies in four different countries. J. Clin. Microbiol. 37: 2274-2279.

Zhou J., J. Zhang, C. Xu and L. He. 2004. CagA genotype and variants in Chinese Helicobacter pylori strains and relationship to gastroduodenal diseases. J. Med. Microbiol. 53: 231-235. 